\title{
Use of Neutral Electrolysed Water (EW) for Quality Maintenance and Shelf-Life Extension of Minimally Processed Lettuce
}

\author{
Daniel Rico \\ Technological University Dublin, daniel.rico@tudublin.ie \\ Ana Belen Martin-Diana \\ Technological University Dublin, anabelen.martindiana@tudublin.ie \\ Catherine Barry-Ryan \\ Technological University Dublin, Catherine.Barryryan@tudublin.ie
}

See next page for additional authors

Follow this and additional works at: https://arrow.tudublin.ie/schfsehart

Part of the Food Science Commons

\section{Recommended Citation \\ Rico, D. et al. (2008) Use of neutral electrolysed water (EW) for quality maintenance and shelf-life extension of minimally processed lettuce. Innovative Food Science \& Emerging Technologies 9, 37-48.doi:10.1016/j.ifset.2007.05.002}

This Article is brought to you for free and open access by the School of Food Science and Environmental Health at ARROW@TU Dublin. It has been accepted for inclusion in Articles by an authorized administrator of ARROW@TU

Dublin. For more information, please contact arrow.admin@tudublin.ie, aisling.coyne@tudublin.ie, gerard.connolly@tudublin.ie.

Funder: Technological Sector Research grant (2002-2006) and International Collaboration Award Scheme (ICAS) (2005-2007).

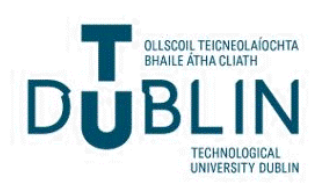




\section{Authors}

Daniel Rico, Ana Belen Martin-Diana, Catherine Barry-Ryan, Jesus Maria Frias, Gary Henehan, and José Barat 


\section{Full Title}

Use of neutral electrolysed water (EW) for quality maintenance and shelf-life extension of minimally processed lettuce.

\section{Running Title}

Efficacy of neutral electrolysed water (EW) on fresh-cut lettuce

\section{Name(s) of Author(s)}

Daniel Rico $^{\text {a }, ~ A n a ~ B . ~ M a r t i ́ n-D i a n a ~}{ }^{\text {a }}$, Catherine Barry-Ryan ${ }^{\text {a }}$ Jesus M. Frías ${ }^{\text {a }}$, Gary T. M. Henehan ${ }^{\mathrm{a}}$, and Jose M. Barat ${ }^{\mathrm{b}}$

$$
\text { and }
$$

\section{Author Affiliation(s)}

${ }^{\mathrm{a}}$ School of Food Science and Environmental Health, Postharvest Research Unit, Dublin Institute of Technology (DIT), Cathal Brugha, Dublin 1. Ireland. Phone: +35314024458 , Fax: +35314024495 .

${ }^{\mathrm{b}}$ Institute of Food Engineering for Development, Department of Food Technology, Universidad Politécnica, Camino de Vera s/n, 46022, Valencia. Spain. Phone: +34963877365, Fax: +34 963877369 


\begin{abstract}
Experiments were conducted to determine the effectiveness of different treatments based on the use of neutral electrolysed water (EW) on fresh-cut lettuce. EW was diluted to obtain different free chlorine concentrations (120, 60 and $12 \mathrm{ppm})$ and compared with standard washing treatment of $120 \mathrm{ppm}$ chlorine solution. Shelf-life quality and safety markers were studied at the beginning and at the end of the 7-day storage at $4{ }^{\circ} \mathrm{C}$. The use of $\mathrm{EW}$ decreased the respiration rate of the samples which might be related with the observed reduction in microbial spoilage. The use of EW also increased the activity of a browning-related enzyme (polyphenoloxydase) although sensory results showed all samples as acceptable at the end of the 7 day-storage. Perhaps longer storage time might increase the risk to browning development in the samples treated with EW. The highest EW concentration (120 ppm free chlorine) was the most effective treatment in reducing sample microbial load; however this treatment also affected the final produce with effects such as loss of turgor, plasmolysis and a reduction in mineral content.

Results suggest an intermediate EW concentration with 60 ppm free chlorine could be an alternative to $120 \mathrm{ppm}$ chlorine (from sodium hypochlorite) for sanitizing fresh-cut vegetables, reducing to the half the amount of chlorine used and maintaining the antimicrobial effectiveness and without differences affecting the quality. However further studies will be necessaries in order to observe the effect of the oxidising capacity of EW on other quality and safety markers as pathogens and nutritional content.
\end{abstract}

Keywords: Neutral activate water, lettuce, quality, decontamination, fresh-cut, minimally processed. 


\section{Industrial relevance:}

Chlorine solutions have been widely used to sanitise fruit and vegetables in the freshcut industry. However, the association of chlorine with the possible formation of carcinogenic chlorinated compounds in water has called into question the use of chlorine in food processing.

The efficacy in controlling the microbial load and browning of samples treated with electrolysed water shows it as a promising decontaminant agent for fresh-cut lettuce. Due to the high oxidising potential of the EW quality requirements must be balanced to obtain the optimal treatment conditions keeping satisfying safety levels. The use of EW60 showed similar safety and quality (browning) results as the use of chlorine or double EW concentration (EW-120). However the treatment EW-120 affected negatively to textural properties. The study suggests the use of EW-60 as alternative to sodium hypochlorite solution with $120 \mathrm{ppm}$ available chlorine, obtaining similar safety and quality results and reducing the amount of chlorine needed. Further investigations in the effect of EW on lettuce, such as those on pathogens or nutritional markers (e.g. carotenoids and vitamin C) are recommended in order to explore this alternative that might reduce the increasingly concerning use of chlorine to decontaminate this type of product.

\section{Introduction}

The fresh-cut fruit and vegetable market has undergone a rapid growth within the food industry. Much of the growth has come from the healthy alternative in restaurants, but also the change of new trends in life-style, increased awareness of the importance of diet for health (Willey, 1994; Parish, Beuchat, Suslow, Harris, Garret, Faber \& Busta, 2003). There has been growth in public knowledge about how diet and health are linked and the importance of maintaining physical fitness throughout life. These claims can be seen to have benefited both fresh and processed fruits and vegetables in that the balance 
between the fresh and processed products is virtually unchanged from the balance that existed 20 years ago. Although it is a new market it represents $20 \%$ of the total of vegetable sales in supermarkets (Piagetini, Mendez, Guemes \& Pirovani, 2005).

However, the marketing of fresh-cut vegetables is limited by their short and their decline in post-processing quality. This is due to undesirable biochemical reactions associated with wounding when compared to non-treated vegetables (Watada, 1997; Brecht, 1995).

Food spoilage can be defined in several ways; generally a fresh-cut product is considered spoiled when it is no longer acceptable to the consumer (Singh \& Anderson, 2004). The worst case of spoilage it is considered when affect to the safety, however changes in quality (browning, off-odours, and loss of textures) can be considered spoilage since deteriorated that point that it is no longer acceptable.

Chlorine has been the biocide of choice for the fruit and vegetable industry for many decades. When used correctly, it is regarded as both inexpensive and effective. Many regulations and guidelines applied to the food industry stipulate minimum free chlorine concentrations in water streams. Chlorine and chlorine derivatives, in particular, have become a focus for environmental concern, and some environmental groups suggest a phase-out of chlorine use globally. The United States Environmental Protection Agency (US EPA) has initiated studies and rulemakings which support that direction (Garfield, 1995).

Since disinfection and decontamination is an important and inevitable step in ensuring the safety and extend the shelf-life of ready to eat vegetables a generation of a new trend in order to find new alternatives to chlorine derivates. Among these alternatives can be included organic acids, essential oil treatments, irradiation, heat-shock or ozone. A compromise must be reached between palatability (quality), safety and nutrition in the final product when using fresh-cut products due to the high liability; however 
studies have shown that new alternatives cannot guarantee a safety of the minimal processed vegetable (Beuchat \& Ryu, 1997; Beuchat, 1998; Seymour, 1999).

The electrolysed water (EW) is a relative new concept which is based on a new, previously unknown law of anomalous changes of reactional and catalytic abilities of aqueous solutions subjected to electrochemical unipolar (either anoxic or cathodic) treatment. EW of solutions is necessarily associated with alteration of their chemical composition, acidity and (or) alkalinity within a wide range. That is why EW application makes it possible to exclude reagent methods of solution properties' regulation from routine technological processes, to improve production's quality, to reduce the number and duration of technological operations, to decrease their labourconsuming nature, to facilitate and simplify processes of sewage purification.

Unlike well-known electrochemical procedures, in the processes of electrochemical activation initial substances are diluted aqua-saline solutions, fresh or low-mineralised water, i.e. liquids of low electric conductivity. The eventual EW products are not concentrated chemical substances, but activated solutions, that is, low mineralised liquids in a meta-stable state, manifesting increased chemical activity in relaxation period. Synthesis of electrochemically activated solutions is only possible when unipolar electrochemical exposure is combined with treatment of as many as possible micro volumes of liquid in a high voltage electric field of a double electric layer near the electrode's surface.

The above stated conditions of producing activated solutions can be realised only in special technical electrochemical systems. Some examples of the practical application of electrochemically activated solutions are given for sterilising solutions in medicine (Lee, Guo, Lam \& Lau, 2004a, Lee, Rhee, Kim, Kim, Paik, Rhee, Song, Yeom \& Lee, 2004b, Vorobjeva, Vorobjeva \& Khodjaev, 2004), swimming-pool water disinfection, food sanitation (Park, Hung \& Brackett, 2002, Bari, Sabina, Isobe, Uemura \& Isshiki, 
2003, Sharma \& Demirci, 2003) and drinking water purification, experimentally in agriculture (Al-Haq, Seo, Oshita, Kawagoe, 2002; Buck, Van Iersel, Oetting \& Hung, 2003), livestock management (Stevenson, Cook, Bach \& McAllister, 2004), and food sanitisation and in areas that rely on antimicrobial methodologies (Park et al., 2002; Fabrizio \& Cutter, 2003).

EW has a strong bactericidal effect against pathogens and spoilage microorganism, more effective than chlorine due to high oxidation reduction potential (ORP) (Bari et al., 2003, Izumi, 1999; Kiura, et al., 2002; Koseki \& Itoh, 2001a). The advantage of the use of $\mathrm{EW}$ at neutral $\mathrm{pH}$ in comparison with acid is this does not affect to $\mathrm{pH}$, surface colour or general appearance of fresh-cut vegetable (Izumi, 1999)

A few studies have been reported in fresh-cut vegetables (Ongeng, Devlieghere,Devevere, Coosemans \& Ryckeboer, 2006: Wang, Feng \& Luo, 2004; Izumi, 1999; Koseki \& Itoh, 2001a).The major part of these studies are focused in a microbial point of view and a few take account about quality aspects (browning, textures, sensory, etc.).

The aim of this study was to investigate the effect of the use and concentration of neutral EW on fresh-cut lettuce during the storage and compare the result with the standard chlorinated method use in the industry. Since the possibility of reduce chlorine totally or partially presents advantages, shorter periods of storage 7 days will be investigated to analyse the effect of a wide range of EW compared with chlorine.

\section{Materials and Methods:}

\subsection{Experimental design.}

Five independent trials (Figure 1) were carried out between September 2005 and June 2006. For colour and texture analysis all pieces in the storage bag were individually analysed to minimise the variability of the product. For sensory analysis samples from the whole storage bag were analysed throughout all storage. For destructive analysis 
( $\mathrm{pH}$, water content, water activity, minerals, enzymes and microbiology) samples were taken from a pool of all the pieces in a storage bag.

\section{-Figure 1 over here-}

\subsection{Processing raw material.}

Iceberg lettuce (Lactuca sativa sp.) is one of the most popular vegetable consumed as minimally processed (ready to eat salads). The produce was grown in Valencia (Spain) and purchased from a local grower. The lettuce was brought to the laboratory within 12 hours after the harvest and stored at $4{ }^{\circ} \mathrm{C}$ before processing. The two outer leaves were removed by hand and the core was excised with a stainless steel knife. The remaining head of lettuce was cut into halves and each half was further cut into six pieces. The temperature in the processing plant was $25^{\circ} \mathrm{C}$ (Figure 1).

\subsection{Preparation of treatment solutions}

Chlorinated water was prepared by adding sodium hypochlorite solution $(\geq 120 \mathrm{~g} / \mathrm{L}$ chlorine) to distilled water to obtain a final solution containing $120 \mathrm{mg} / \mathrm{L}$ chlorine $(\mathrm{pH}$ 8). Free chlorine concentration in the washing water was determined using a DREl/2000 spectrometer with appropriate AccuVac ${ }^{\circledR}$ pillows (Hach Company, Loveland, Colorado, USA), using the DPD method (Date et al., 2002).

EW was provided for the experimental analysis by Envirolyte (Aqua Rioja, Madrid, Spain) (Figure 2). The water was produced using an Eurostel unit (Figure 2, I), using 1$4 \%$ table salt solution as initial material for producing electrochemically treated solutions (Figure 2, II). In order to produce Neutral Anolyte $90 \%$ of the initial solution is passed through the anode II and $10 \%$ through the cathode chambers. 5-10\% of the full amount of Catholyte is mixed with Anolyte. The mixture is called "neutral" Anolyte. The EW has a $\mathrm{pH}$ of 6.5 and an oxidizing redox potential (ORP) of 750$900 \mathrm{mV}$. The amount of free chlorine was measured (500 ppm) using a DREl/2000 spectrometer with appropriate AccuVac ${ }^{\circledR}$ pillows (Hach Company, Loveland, 
Colorado, USA), using the DPD method. Three EW dilutions were prepared: EW-120, EW-60 and EW-12 ( 120, $\sim 60$ and $\sim 12 \mathrm{mg} / \mathrm{L}$ free chlorine respectively).

\section{-Figure 2 over here-}

Treatments were carried out in different baskets ( 200 g vegetable product/L) and immersed in the solution for 1 min with agitation and subsequently dried for 5 min using an automatic salad spinner. To minimise product heterogeneity, processed vegetables were pooled, mixed and subsequently packaged in bags $(200 \times 320 \mathrm{~mm})$ of $35 \mu \mathrm{m}$ oriented polypropylene (OPP) (Amcor Flexibles Europe-Brighouse, United Kingdom). The permeability of the film was with oxygen and carbon dioxide transmission rates of $\sim 12,000 \mathrm{ml} \mathrm{m}^{-2}$ day $^{-1}$ atm $^{-1}$ and $\sim 13,000 \mathrm{ml} \mathrm{m}^{-2}$ day $^{-1}$ atm $^{-1}$ at 5 ${ }^{\circ} \mathrm{C}$, respectively. Each package contained $\sim 100 \mathrm{~g}$ of product. The packages were chilled in a blast freezer at $0{ }^{\circ} \mathrm{C}$ for 2 minutes before heat-sealing under atmospheric conditions. The final processed product was stored for 7 days at $4{ }^{\circ} \mathrm{C}$.

\subsection{Shelf-life analysis}

An evaluation of quality and safety markers was carried out 1 day after the treatment and after a significant part ( 7 days) of the shelf-life of the products storage at $4{ }^{\circ} \mathrm{C}$.

\subsubsection{Quality markers}

Different quality markers were used to compare the effect of chlorine and EW in fresh-cut lettuce. Respiration markers (Headspace), textural markers (Cryo-SEM and Instron), browning markers (colorimeter, potential browning and polyphenol oxidase), physiological markers ( $\mathrm{pH}$, water content, water activity and minerals) and sensory markers (sensory analysis).

\subsubsection{Respiration markers}

Headspace. A gaspace analyser (PBI Dansensor, model CheckMate 9900, Ringsted, Denmark) was used to monitor levels of carbon dioxide $\left(\mathrm{CO}_{2}\right)$ and Oxygen $\left(\mathrm{O}_{2}\right)$ during storage. Gas extraction was performed with a hypodermic needle, inserted through an 
adhesive septum previously fixed to the bag, at a flow rate of $1.5 \mathrm{~mL} / \mathrm{min}$ for 1 minute, monitoring with a sensitivity of $0.001\left(\mathrm{O}_{2}\right)$ and $0.1\left(\mathrm{CO}_{2}\right)$. The accuracy is in percentage of readings: $\pm 1 \%$ of the reading in the calibrated range and $\pm 2 \%$ of the full range for $\mathrm{CO}_{2} .3$ bags per treatment were monitored for each experiment and the rest of bags used for other analyses were also measured.

\subsubsection{Textural markers}

Cryo scanning electron microscopy (Cryo-SEM) was used to observe the effects of wounding stress on processed samples. Rectangular pieces 4 x $5 \mathrm{~mm}$ were cut from the wounded area to the centre of the samples. The samples were frozen by immersion in Slush Nitrogen $\left(-210^{\circ} \mathrm{C}\right)$. After that, the samples were fractured, etched (at $-94.5^{\circ} \mathrm{C}, 10^{-}$

${ }^{5}$ Torr vacuum, for 15 minutes), gold coated and viewed in the cold-stage scanning electron microscope (JEOL JSM-5410). Using this technique, the fractured surface of the frozen sample was viewed directly while being maintained at $-150{ }^{\circ} \mathrm{C}$ or lower (Bomben \& King, 1982). Two samples per treatment and day were used and $~ 10$ micrographs per sample were obtained.

Texture analysis: Texture properties of lettuce were assessed using an Aname texture analyser (Stable Micro Systems, model TA.XTPlus, London, United Kingdom). A 500 $\mathrm{N}$ load cell was attached. For lettuce a shear cell (Flexion-Fracture) with 1 blade probe attached to the instrument was used. The speed setting for the experiment was 100 $(\mathrm{mm} / \mathrm{min})$ and maximum load was reported $(\mathrm{KN} / \mathrm{g})$. The instrumental measurement of lettuce texture is difficult to carry out, due mainly to the high variability of the product. Values were expressed as the rate max. load/distance (at break point). More than 25 samples were analysed per treatment and day.

\subsubsection{Browning markers}

Colour was assessed using a colorimeter (Minolta, Model CM-3600d, United Kingdom). A lettuce piece was placed directly on the colorimeter sensor $(3.5 \mathrm{~cm}$ of 
diameter) and measured; 20-30 measurements were taken per treatment and day. The instrument was calibrated using a white tile $\left(\mathrm{L}^{*}=93.97, \mathrm{a}^{*}=-0.88\right.$ and $\left.\mathrm{b}^{*}=1.21\right)$ and a green tile $\left(\mathrm{L}^{*}=56.23, \mathrm{a}^{*}=-21.85, \mathrm{~b}^{*}=8.31\right)$ standards. The $\mathrm{L}^{*}$ parameter (lightness index scale) range from 0 (black) to 100 (white). The $\mathrm{a}^{*}$ parameter measures the degree of red $(+a)$ or green $\left(-a^{*}\right)$ colour and the $b^{*}$ parameter measures the degree of yellow $(+b)$ or blue $\left(-b^{*}\right)$ colour.

Potential browning was measured according with the methodology of Viňa \& Chaves (2006). Ten grams of tissue frozen and crushed were treated with ethanol $96^{\circ} \mathrm{C}$ for 60 minutes and then centrifuged at $6000 \mathrm{rpm}$ at $10{ }^{\circ} \mathrm{C}$ during 10 minutes retaining the supernatants. Ethanol was added to complete the final volume to $25 \mathrm{~mL}$. Absorbance at $320 \mathrm{~nm}$ was measured on aliquots of this extracts. The result was expressed as absorbance units (AU) $\mathrm{g}^{-1}$ fresh tissue.

Polyphenol oxidase (PPO) E.C.1.10.3.1, a browning-related enzyme, was assayed in homogenates prepared as follows: $10 \mathrm{~g}$ of vegetable were mixed with $20 \mathrm{~mL}$ of $0.5 \mathrm{M}$ phosphate buffer $\mathrm{pH} 6.5$ containing $50 \mathrm{~g} / \mathrm{L}$ polyvinylpyrrolidone and placed in a UltraTurrax homogeniser (Ika-Labortechnik, model UltraTurrax T25, Staufen, Germany). Homogenisation was carried out in two steps of 1 minute, at $5500 \mathrm{rpm}$ and at $4{ }^{\circ} \mathrm{C}$, with a break of $3 \mathrm{~min}$ in order to avoid excess of heating to the sample. The homogenate was then centrifuged at $12,720 \mathrm{x} \mathrm{g}$ for $30 \mathrm{~min}$ at $4{ }^{\circ} \mathrm{C}$ and supernatant filtered through one layer of crepe bandage. The resulting crude extract was used without further purification. All the extracts were kept at $4{ }^{\circ} \mathrm{C}$ and dark conditions and used immediately.

PPO activity was assayed spectrophotometrically (Thermo electron corporation, model CE 1020, Madrid, Spain) by a modified method based on Galeazzi, Sgarbieri \& Constantinides (1981) and Tan \& Harris (1995). The reaction mixture contained $0.1 \mathrm{~mL}$ crude extract and $2.9 \mathrm{~mL}$ substrate solution $(0.02 \mathrm{~mol} / \mathrm{L}$ catechol in $0.05 \mathrm{~mol} / \mathrm{L}$ 
phosphate buffer, $\mathrm{pH}$ 6.5). Catechol oxidation was followed at $400 \mathrm{~nm}$ for $2 \mathrm{~min}$ at 25 ${ }^{\circ} \mathrm{C}$. An enzyme activity unit was defined as an increase of 0.1 in absorbance per minute.

\subsubsection{Physiological markers}

pH was measured using $10 \mathrm{~g}$ sample blended for $2 \mathrm{~min}$ in $20 \mathrm{~mL}$ of deionised water. The $\mathrm{pH}$ of the slurry was measured at room temperature using a $\mathrm{pH}$-meter (Consort, model C830, Turnhout, Belgium) between $18-20^{\circ} \mathrm{C}$.

Water content. Pieces of lettuce were heated at $100{ }^{\circ} \mathrm{C}$ for 2 hours in a Universal Oven (Memmert, Schwabach, Germany) and weighted before and after the heating. Four replicates per treatment and day were carried out. The water content was calculated as mg of water per $g$ of sample.

Water activity of the treated samples was measured with a fast water activity meter (GBX scientific FA-st/1, Cédex, France). A piece of lettuce $(\sim 5 \mathrm{~g})$ was placed inside a small plastic cup and on the base of the air tight test chamber. The measuring head enclosed the sample and formed an airtight seal with the base. At least 15 samples were measured per treatment and day.

Mineral content was analysed after the treatment using a Metrohm advanced ion chromatography system equipped (Herisau, Switzerland) with Model 761 IC Pumps, Metrohm Spark Triathlon autosampler and 817 Bioscan Pulsed amperometric detector. Data acquisition and processing were performed with Metrohm IC-Net 2.3 software. Bioscan temperature was controlled at $25^{\circ} \mathrm{C}$. The injection volume was $20 \mu \mathrm{L}$. The column employed for cation analysis was a Metrosep C2 150 analytical column (150 $\mathrm{mm} \times 4 \mathrm{~mm})$ and the mobile phase was aqueous Tartaric acid $(4.0 \mathrm{mM})$ and dipicolinic acid $(0.75 \mathrm{mM})$. The flow rate used was $1 \mathrm{~mL} / \mathrm{min}$. For anion analyses a metrosep a supp 5-250 (250 x $4 \mathrm{~mm})$ column was used. The eluent was sodium hydrogen carbonate $(1 \mathrm{mM})$ and sodium carbonate $(3,2 \mathrm{mM})$.

\subsubsection{Sensory markers}


Sensory analysis of the samples was performed over 7 days (at day 1 and day 7) of storage time by a panel of trained members (12) with an age range of 20-35 years was selected from among the members of the Department of Food Science and Technology of the University Politecnica of Valencia. The panellists had previously participated in evaluating quality of fresh cut vegetable. Fresh appearance, photosynthetic browning, vascular browning and general acceptability of samples were scored on a hedonic scale of 1 to 5 .

(1) Fresh appearance, where 5=very good/ fresh appearance, 3=moderate, and 1=poor/no fresh appearance; (2) Vascular Browning, where 5=none, 3=moderate/vascular bundles reddish-brown (punctual spots), and 1=severe; (3) Photosynthetic Browning, where 5=none, 3=moderate/vascular bundles reddish-brown (punctual spots), and 1=severe; (4) General acceptability, where 5=very good, $3=$ moderate and $1=$ poor/no acceptable from consumer point of view.

The applied cut off for the different attributes was fixed at 3 and scores below 3 indicated unacceptable samples.

\subsubsection{Safety markers}

Mesophilic load as indicators of microbiological growth were carried out on the samples before and after the treatment at regular intervals through the storage period (day 0 before and after the treatment, day 1 and day 7). $25 \mathrm{~g}$ of vegetable were blended in $225 \mathrm{~mL}$ of peptone saline with a Stomacher circulator homogenizer. A total count enumeration was carried out as at $30{ }^{\circ} \mathrm{C}$ on plate count agar (PCA) incubated for 72 hours. The results were expressed as $\log _{10}$ colony forming units per gram (CFU/g). Due to the huge variability for the leafy products (lettuce) the samples for microbiological assays were taken from the top part of the head of the lettuce.

\subsubsection{Statistical analysis}


Analysis of ANOVA (Multifactor and one-way) were used to find differences between treatments, storage and interaction of both factors for each one of the variables studied. Means were compared by Least Significant Difference (LSD) test, at a significance level $\mathrm{p}=0.05$ using the Statgraphics software (version 2.1; Statistical Graphics Co., Rockville, USA). Five independent trials were carried out.

\section{Results and Discussion}

\subsection{Quality markers}

\subsubsection{Respiration markers}

Headspace: Fresh-cut lettuce is much more perishable than the whole lettuce head due to the stress produced after the minimally procedure. This effect is observed immediately in respiration changes. Cantwell (1998) and Watada, Ko \& Minott (1996) described that the respiration rate going to over $100 \%$ in lettuce and the consumption of oxygen was two times that of the intact lettuce for shredder (Ballantyne, 1986).

Figure 3 shows the changes of headspace gas concentration. Oxygen and carbon dioxide significantly $(\mathrm{p}<0.05)$ decreased and increased respectively during storage for all treatments, as expected (Figure 3, I).

\section{-Figure 3 over here-}

The oxygen values measured at day 1 (24 hours after package sealing) showed significant $(\mathrm{p}<0.05)$ decreases, to values ranging $18 \%(\mathrm{EW}-120$ samples) to $15 \%(\mathrm{EW}$ 12 samples). A higher EW concentration treatment caused lower respiration rate in the samples. Chlorinated samples showed intermediate values of respiration rate. At the end of the storage (Day 7) all the treatments reached similar oxygen values with no significant differences $(\mathrm{p}>0.05)$ between treatments.

Carbon dioxide (Figure 3-II) reached final concentrations of around $5 \%$ to $6 \%$. The low levels of carbon dioxide observed prevented anoxic conditions and therefore 
fermentative processes associated which might cause the formation of acetaldehyde and the appearance of off-flavours compounds (Kays, 1991).

The lowest levels of respiration rate after the treatments were observed in samples treated with EW-120, treatment that might produce a delay in quality loss of the product and maintain a lower microbial spoilage and therefore a major control of the damage produced by the minimally processing.

\subsubsection{Textural markers}

Cryo-SEM: Micrographs (Cryo-SEM) of fresh-cut lettuce were carried out over 7 days storage at $4{ }^{\circ} \mathrm{C}$ for samples treated with chlorine (I) and EW (EW-120 (II), EW-60 (III) and EW-12 (IV)) at room temperature $\left(20-25^{\circ} \mathrm{C}\right)$. At day 1, photosynthetic tissue from each lettuce sample was analysed in order to observe structural changes at a microscopic level. Wounded areas affected by the minimal process were selected in all cases, and the sample tissues were oriented to obtain fracture surfaces perpendicular to vascular axes.

Cryo-SEM images showed the internal cellular features as a dispersed network cellular material that seemed to have been pulled away, in agreement with other authors (Roy, Watada, Conway, Erbe \& Wergin, 1994) might correspond to membrane and cell wall fragments which are dispersed after the sublimation process used for sample preparation.

Figure 4 shows samples one day after the treatment. At day 1 no differences between samples were observed. The cells showed a smooth external surface with a slightly cytoplasmatic shrinkage (Figure 4 marked with S) of the cells, indicating that lettuce cell structure degradation might have started perhaps due to the release of exudate after the wounding. For all treatments the cell walls appeared well-defined and although there was not a visible gap in the middle lamella and incipient definition of this gap, which is associated with pectin solubilisation (Figure 4, marked with $\mathrm{P}$ ) and the 
subsequent reduction of adhesion between cells (Varela, Salvador \& Fiszman, 2005), was observed. No such gaps were observed in the internal tissues after the treatment, indicating that the degradation of the texture might be limited to the external areas, as a result of the wounding process.

\section{-Figure 4 over here-}

Figure 5 shows the results after 7 days of storage. In chlorinated samples the cells acquired polyhedral shapes (Figure 5I), phenomenon observed in less degree in EW treated samples, were the form of the cells remained more rounded. This might reflect a higher turgidity or water content in the samples treated with EW compared with the samples treated with chlorine. However although remaining more turgid than chlorinated a bigger "gap" between cell and middle lamella was observed in samples treated with higher concentrations of EW (Figure 5 II, III and IV), indicating more plasmolysis and pectin solubilisation. The appearance of this gap can be due to pectin solubilisation favouring softening of the cell wall and cell separation (Kunzek, Kabbert \& Gloyna, 1999). The micrographs indicated that higher concentration of EW produced bigger gaps. This could be due to the oxidising capacity of the EW. This is in agreement with Hong \& Gross (1998) which considered that oxidising agents could cause oxidation of feruloylated or phenolic cross-linkages among cell wall pectin, structural proteins or other polymers, and thereby change the firmness of the product.

At the end of the storage samples treated with EW-12 showed a more integrity of the cells and turgidity than EW-120, EW-60 or chlorinated samples.

\section{-Figure 5 over here-}

\section{Texture analysis}

Fractural text was used as the simplest test in which a force is applied on the vertical axis in order to fracture the sample. A significant difference $(\mathrm{p}<0.05)$ between treatments was observed (Figure 6). Samples treated with EW-120 showed a significant 
increase in the maximum load/distance during the storage compared with samples treated with chlorine or EW-60 or EW-12. This increase in load might be associated rather than with a freshness characteristic of the sample, with a loss of water content, producing dehydration of the tissues and an increase in elasticity during the storage. The results obtained with Cryo-SEM showed samples treated with EW-120 with bigger separations or gaps between cell wall cell membrane.

\section{-Figure 6 over here-}

No significant differences $(\mathrm{p}>0.05)$ between chlorinated and EW-60 were observed. Samples treated with lower concentrations of EW-12 showed lower textural values, which can be an indicative of a major crispness of the sample, since lower forces are necessary to fracture them.

\subsubsection{Browning markers}

Colour analysis is considered to be one of the most important external factors of freshcut vegetables, as the appearance of the vegetable highly influences consumers. Colour changes of fresh-cut lettuce were evaluated using colour parameters $L^{*}, a^{*}$ and $b^{*}$. Figure 7 shows the luminosity $\left(\mathrm{L}^{*}\right)$ values; a significant $(\mathrm{p}<0.05)$ decrease during the storage was observed in all the samples regardless of the treatment. Decrease in luminosity is associated with browning appearance and quality loss.

\section{-Figure 7 over here-}

Lightness index values were significantly $(\mathrm{p}<0.05)$ higher in EW treated fresh-cut lettuce $(\sim 67-69)$ than in chlorinated treated samples $(\sim 65)$. The high luminosity in lettuce treated with EW could be due to the blanching effect on the tissue due to the oxidizing capacity of EW, which could cause air removal around the fine hairs on the surface of the plant and the expulsion of air between the cells that can be observed with an increased in luminosity. After 7 days of storage samples treated with chlorine 
reached similar values to samples treated with EW-120 or EW-60, meanwhile samples treated with EW-12 reached the highest luminosity values.

Browning is not only due to enzymatic processes, and in this experiment inverse relation was observed for the results of luminosity (browning indicator) and browningrelated enzyme (PPO) activity. Higher concentrations of EW might have produced more damage to the tissues, increasing the chances of non-enzymatic browning appearance.

The $\mathrm{a}^{*}$ parameter increased significantly $(\mathrm{p}<0.05)$ during storage, with no significant ( $p>0.05)$ differences due to the washing treatment. Changes in $a^{*}$ parameter can be associated to degradation of chlorophyll pigments. All the treatments maintained $\mathrm{a}^{*}$ values at similar levels at day 7 (data not shown). The $b^{*}$ parameter decreased during the storage with no significant $(\mathrm{p}>0.05)$ differences between treatments (data not shown).

Potential browning results are shown in Figure 8. Potential browning significantly $(p<0.05)$ increased over the storage in all the samples. Chlorinated samples showed higher values than samples treated with EW. The use of EW appeared to have a positive effect in controlling the potential browning of the samples.

\section{-Figure 8 over here-}

Polyphenol oxidase $(P P O)$ activity showed significant $(\mathrm{p}<0.05)$ lower values in samples treated with high EW solutions (EW-120 EW-60) than those treated with lower EW solutions (EW-12) or chlorinated samples (Figure 9). This behaviour might respond to the oxidizing effect of EW, partially deactivating the enzyme. EW as other powerful oxidants can react with many organic compounds (aromatic amino acids such as tyrosine and tryptophan and sulfur-containing amino acids such as cysteine and methionine) (Hardy, 1997). The deactivation found after the EW washing treatment of PPO may be due to oxidation of the amino acids and/or disulfide bonds that are involved in the active site in the PPO. PPO activity levels were similar to those found in 
samples treated with chlorine when the EW was used at the lowest concentration (EW12).

\section{-Figure 9 over here-}

\subsubsection{Physiological markers}

$p H$. A significant $(\mathrm{p}<0.05)$ reduction in $\mathrm{pH}$ was observed in samples treated with $\mathrm{EW}$ 120 than chlorinated or EW-60 and EW-12 after the treatment (Table 1). After 7 days of storage a general increase of $\mathrm{pH}$ was observed in all samples regardless of the treatment. EW-120 showed lower $\mathrm{pH}$ values than the other treatments, which could be due to the inhibitory effect of EW on gram negative bacterial growth.

\section{-Table 1 over here-}

Water content was measured throughout the storage (Table 1). Water content did not change significantly during the storage. Samples treated with EW-120 and EW-60 showed significant higher water content values than those treated with EW-12 and chlorine.

Water activity was measured in all samples during the storage (Table 1). A significant decrease in water activity was observed during the storage. However although water activity is considered an indirect indicator of growth of microorganisms and most degradation reactions of a chemical, enzymatic, and physical nature, no significant differences $(p>0.05)$ in water activity between treatments were observed, meanwhile differences due to the treatment in browning and microbial growth were found . (Figures 8, 9 and 10).

Mineral content. Table 2 shows mineral content $\left(\mathrm{mg} \mathrm{L}^{-1}\right)$ of the samples treated with EW and chlorine. Sodium, potassium and calcium content appeared to be affected by the use of EW as well as the concentration of the treatment, but not in the case of the magnesium. Treatment with EW-120 produced a significant $(\mathrm{p}<0.05)$ reduction of the minerals compared with EW-60 and EW-12. Similar or lower levels of minerals, except 
magnesium, were present in samples treated with chlorine when compared with those treated with EW. The oxidising strength of the EW might be responsible for the mineral loss.

-Table 2 over here-

\subsubsection{Sensory markers}

Sensory analysis: Sensory quality attributes (fresh appearance, photosynthetic browning, vascular browning and general acceptability) scores showed significant $(\mathrm{p}<0.05)$ decreases during the storage, as expected due to product decay (Table 3 ).

\section{-Table 3 over here-}

The treatment significantly $(\mathrm{p}<0.05)$ affected sample scores for appearance, browning and acceptability both immediately after the treatment (day 1) and at the end of the experiment (day 7). Samples treated with chlorine scored for the best sensory results followed by those treated with EW-120, EW-60 and finally EW-12.

Photosynthetic (PB) and vascular (VB) browning were evaluated in separated questions, as these two type of browning appear not necessarily at the same time (Fukumoto, Toivonen, Delaquis, 2002). A major incidence of PB was observed in samples treated with EW-60 and EW-12, meanwhile lower values were scored by chlorine and EW-120 treated samples. At the end of the storage same differences were kept between treatments and significantly $(\mathrm{p}<0.05)$ less browning was observed in samples treated with chlorine and EW-120.

The VB showed different behaviour than PB. No differences between chlorinated and EW-120 and EW-60 were observed after the treatment. At the end of the storage samples treated with EW-12 showed values lower than 3, below the acceptability cutoff point.

General acceptability scored similar values for samples treated with chlorine and EW120, significantly higher than those scored for samples treated with EW-12. At the end 
of the storage, the panellist considered acceptable all the samples, but the best treatments were chlorine and EW-120.

\subsection{Safety markers}

Mesophilic are the predominant microflora of processed lettuce, consisting of aerobic, psychotropic and gram-negative bacilli. For this reason mesophilic bacteria were monitored throughout all the storage as an indicative quality marker (Figure 10).

\section{-Figure 10 over here-}

Fresh-cut lettuce showed before washing mesophilic counts lower $(4 \log )$ than reported in previous works (Martin-Diana, Rico, Barry-Ryan, Frias, Mulcahy \& Henehan, 2005 Martin-Diana, Rico, Frias, Mulcahy, Henehan \& Barry-Ryan, 2006). This may be due a number of factors that are difficult to control as ambient condition during the postharvest period, amount of soil and irrigation conditions amongst others (Ponce, Roura, Del Valle \& Fritz, 2002).

All the treatments (chlorine and EW-120, EW-60 and EW-12) showed a significant reduction of mesophilic counts $(\mathrm{p}<0.05)$ after the washing $(\sim 2.2-2.4 \log )$ compared with lettuce treated with water $(0.8 \mathrm{log})$. No differences between chlorinated and EW samples were observed one day after the washing treatment. The reduction in microbial load produced by EW was in agreement with Koseki et al., 2001b, which found reductions of $\sim 2 \log$ in fresh-cut lettuce using EW.

After 1 day of storage mesophilic counts increased to values close to $\sim 3.2 \log$ in the case of samples treated with EW-12. The chlorine treated samples did not show significant differences with those treated with EW-120. EW-60 treated samples showed slightly higher values, although with the last three treatments the microbial load was lower than $2.6 \log$ after 1 day of storage. From day 1 to day 7 samples treated with water reached the highest values $(\sim 4.6 \mathrm{log})$ followed by samples treated with EW-12 $(\sim 3.9 \log )$. Significant lower values $(\mathrm{p}<0.05)$ were found in samples treated with 
chlorine and EW-60 ( 3.6 log), showing the lowest values samples treated with EW$120(\sim 3.2 \log )$.

At day 7 all the samples kept microbial load values within the limit for consumer consumption of fresh processed vegetables ( $8 \log$ for mesophilic bacteria) (Allende, Aguayo \& Artes., 2004).

Further investigations in control of microbial spoilage and protection of consumers against microbiological hazards are recommended to see if the concentrations of EW used in this work, or even lower ones, could control pathogens. Previous studies carried out for other authors showed EW to be more efficient than ozonated water in fruits and vegetables (Koseki et al., 2001b), and yield similar results to chlorinated solutions (Park et al. 2002; Kim, Hung, Brackett \& Lin, 2003) in the control of pathogens.

\section{Conclusion}

The efficacy in controlling the microbial load and browning of samples treated with electrolysed water shows it as a promising decontaminant agent for fresh-cut lettuce. Due to the high oxidising potential of the EW quality requirements must be balanced to obtain the optimal treatment conditions keeping satisfying safety levels. The use of EW60 showed similar safety and quality (browning) results as the use of chlorine or double EW concentration (EW-120). However the treatment EW-120 affected negatively to textural properties, producing a major loss of turgor and plasmolysis than lower EW concentrations or chlorine.

The study suggests the use of EW-60 as alternative to sodium hypochlorite solution with 120 ppm available chlorine, obtaining similar safety and quality results and reducing the amount of chlorine needed. Further investigations in the effect of EW on lettuce, such as those on pathogens or nutritional markers (e.g. carotenoids and vitamin

C) are recommended in order to explore this alternative that might reduce the increasingly concerning use of chlorine to decontaminate this type of product.. 


\section{Acknowledgements}

This research was supported by a Technological Sector Research grant (2002-2006) and International Collaboration Award Scheme (ICAS) (2005-2007). The authors would like to thank the laboratory facilities service at University Politécnica of Valencia and Gemma Briz for technical assistance during the experimentation and AQUA-RIOJA for supplying the electrolysed water.

\section{References}

Al-Haq, M.I., Seo, Y., Oshita, S. \& Kawagoe, Y. (2002). Disinfection effects of electrolyzed oxidizing water on suppressing fruit rot of pear caused by Botryosphaeria berengeriana. Food Research International 35, 657-664.

Allende, A., Aguayo, E. \& Artés, F. (2004). Microbial and sensory quality of commercial fresh processed red lettuce throughout the production chain and shelf life. International Journal of Food Microbiology, 91(2), 109-117.

Ballantyne, A. (1986). Modified atmosphere packaging of selected prepared vegetables. Technical memorandum No. 436. Chipping Campden, UK: Campden Food Res. Assoc. Cited by Varoquaux, P. \& Wiley, R. C. (1994). Biological and biochemical changes in minimally processed refrigerated fruits and vegetables. In R. C. Wiley (Ed.), Minimally processed refrigerated fruits and vegetables. New York, USA: Chapman and Hall Inc.

Bari, M.L., Sabina, Y., Isobe, S., Uemura, T. \& Isshiki, K. (2003). Effectiveness of electrolyzed acidic water in killing Escherichia coli O157:H7, Salmonella enteritidis, and Listeria monocytogenes on the surfaces of tomatoes. Journal of Food Protection $66,542-548$

Beuchat, L.R. (1998). Surface Decontamination of Fruits and Vegetables Eaten Raw: A Review. Food Safety Unit, World Health Organisation, Brussels, Belgium. WHO/FSF/FOS/98.2. 
Beuchat, L.R. \& Ryu, J.H. (1997). Produce handling and processing practices. Emerging Infectious Diseases 3, 459-465.

Brecht JK. (1995). Physiology of lightly processed fruits and vegetables. Horticultural Science 301, 8-22.

Bomben J. \& King CJ. (1982). Heat and mass transport in the freezing of apple tissue. Journal of Food Technology 17, 615-632.

Buck, J.W., Van Iersel, M.W., Oetting, R.D. \& Hung, Y.C. (2003). Evaluation of acidic electrolyzed water for phytotoxic symptoms on foliage and flowers of bedding plants. Crop Protection 22, 73-77.

Cantwell, M. (1998). Introduction to fresh-cut products: maintaining quality and safety. University of California, Postharvest Hort. Series No. 10, Section 1.

Date, S., Terabayashi, S., Matsui, K., Namiki, T., Fujime, Y., 2002. Induction of root browning by chloramine in Lactuca sativa L. grown in hydroponics. Journal of. Japanese Society of Horticultural and. Science 71, 485-489.

Fabrizio, K.A. \& Cutter, C.N. (2003). Stability of electrolyzed oxidizing water and its efficacy against cell suspensions of Salmonella typhimurium and Listeria monocytogenes. Journal of Food Protection 66, 1379-1384.

Fabrizio, K.A. \& Cutter, C.N. (2004). Comparison of electrolyzed oxidizing water with other antimicrobial interventions to reduce pathogens on fresh pork. Journal of Food Protection 68, 463-468.

Fukumoto, L.R., Toivonen, P.M., Delaquis, P.J. (2002). Effect of wash water temperature and chlorination on phenolic metabolism and browning of stored iceberg lettuce photosynthetic and vascular tissues. Journal of Agriculture Food Chemistry, 50 (16), 4503-11. 
Galeazzi, M.A.M., Sgarbieri, V.C. \& Constantinides, S.M. (1981). Isolation, purification and physicochemical characterization of poliphenolxidases (PPO) from dwarf variety of banana (Musa cavendishii, L). Journal of Food Science, 46, 150-155.

Garfield, L.R. (1995). Chlorine compounds, food safety and the environment. UNEP Industry and Environment January -27

Hong, H. J. \& Gross, K. C. (1998). Surface sterilization of whole tomato fruit with sodium hypochlorite influences subsequent postharvest behavior of fresh-cut slices. Postharvest Biology and Technology, 13, 51-58.

Hardy, W. O. (1997). An introduction to chlorine dioxide. North Kingstown, RI: Engelhard Corp.

Hsu, S.Y. (2003). Effects of water flow rate, salt concentration and water temperature on efficiency of an electrolyzed oxidizing water generator. Journal of Food Engineering, 60, 469-473.

Izumi, H. (1999). Electrolyzed water as a disinfectant for fresh-cut vegetables. Journal of Food Science, 64, 536-539.

Kays, S.J. (1991). Postharvest Physiologycal of Perishable Plant Products. New York: Van Nostrand Reinhold.

Kim, C., Hung, Y.C., Brackett, R.E. \& Lin, C.S. (2003). Efficacy of electrolyzed oxidizing water in inactivating Salmonella on alfalfa seeds and sprouts. Journal of Food Protection, 66, 208-214.

Kiura, H., Sano, K., Morimatsu, S., Nakano, T., Morita, C., Yamaguchi, M., Maeda, T. \& Katsuoka, Y. (2002). Bactericidal activity of electrolyzed acid water from solution containing sodium chloride at low concentration, in comparison with that at high concentration. Journal of Microbiological Methods, 49, 285-293. 
Koseki, S. \& Itoh, K. (2001a). Prediction of microbial growth in fresh-cut vegetables treated with acidic electrolyzed water during storage under various temperature conditions. Journal of Food Protection, 64, 1935-1942.

Koseki, S., Yoshida, K., Isobe, S. \& Itoh, K. (2001b). Decontamination of lettuce using acidic electrolyzed water. Journal of Food Protection, 64, 652-658.

Kunzek, H., Kabbert, R. \& Gloyna, D. (1999). Aspects of material science in food processing: changes in plant cell walls of fruits and vegetables. Zeitschrift fur Lebensmittel-Untersuchung und-Forschung A, 208, 233-250.

Lee, S.C., Guo, H., Lam, S.M.J. \& Lau, S.L.A. (2004a). Multi-pathway risk assessment on disinfection by-products of drinking water in Hong Kong. Environmental Research, 94, 47-56.

Lee, J.H., Rhee, P., Kim, J.H., Kim, J.J., Paik, S.W., Rhee, J.C, Song, J.H., Yeom, J.S. \& Lee, N.Y. (2004b). Efficacy of electrolyzed acid water in reprocessing patientused flexible upper endoscopes: comparison with $2 \%$ alkaline glutaraldehyde. Journal of Gastroenterology and Hepatology, 19, 897-903.

Martin-Diana, A. B., Rico, D., Barry-Ryan, C., Frias, J. M., Mulcahy, J. \& Henehan, G.T.M. (2005). Effect of calcium lactate concentration and temperature washing treatments on quality retention of salad-cut Iceberg lettuce. Food Research International, 38, 729-740.

Martin-Diana, A.B., Rico, D., Frias, J., Mulcahy, J., Henehan, G.T.M. \& BarryRyan, C. (2006). Whey permeate as a bio-preservative for shelf life maintenance of fresh-cut vegetables. Innovative Food Science \& Emerging Technologies, 7, 112-123.

Ongeng, D., Devlieghere, F., Devevere, J., Coosemans, J. \& Ryckeboer, J. (2006). The efficacy of electrolysed oxidising water for inactivating spoilage microorganisms in process water on minimally processed vegetables. International Journal of Food Microbiology, 109, 187-197 
Parish, M.E., Beuchat, L.R., Suslow, T.V., Harris, L.J., Garrett, E.H., Farber, J.N. \& Busta, F.F. (2003). Methods to reduce/eliminate pathogens from fresh and fresh-cut produce. Comprehensive Reviews in Food Science and Food Safety, 2, 161-173.

Park, H., Hung, Y. \& Brackett, R.E. (2002). Antimicrobial effect of electrolyzed water for inactivating Campylobacter jejuni during poultry washing. International Journal of Food Microbiology, 72, 77-83.

Piagentini, A.M., Mendez, J.C., Guemes, D.R. \& Pirovani, M.E. (2005). Modeling changes of sensory attributes for individual and mixed fresh-cut leafy vegetables. Postharvest Biology and Technology, 38, 202-212.

Ponce, A.G., Roura, S.I., Del Valle, C.E. \& Fritz, R. (2002). Characterization of native microbial population of Swiss Chaed (Beta vulgaris, type cicla). LebensmittelWissenschaft und-Technologie, 37, 199-204.

Roy, S., Watada, A.E., Conway, W.S., Erbe, E.F. \& Wergin, W.P. (1994). Lowtemperature scanning electron microscopy of frozen hydrated apple tissues and surface organisms. HortScience, 29, 305-309.

Seymour, I.J. (1999). Review of current industry practice on fruit and vegetable decontamination. Review, vol. 14. Campden and Chorleywood Food Research Association Group, Chipping Campden, Gloucestershire, UK, pp. 1-38.

Sharma, R.R. \& Demirci, A. (2003). Treatment of Eschericia coli O157:H7 inoculated alfalfa seeds and sprouts with electrolysed oxidising water. International Journal of Food Microbiology, 86, 231-237.

Singh, R.P. \& Anderson, B.A. (2004). The major types of food spoilage: an overview. In: Steele, R. (Ed.). Understanding and measuring the shelf-life of food. Woodhead Publishing, Cambridge, UK.

Stevenson, S.M.L., Cook, S.R., Bach, S.J. \& McAllister, T.A. (2004). Effects of water source, dilution, storage, and bacterial and fecal loads on the efficacy of 
electrolyzed oxidizing water for the control of Escherichia coli O157:H7. Journal of Food Protection, 67, 1377-1388.

Tan, B. K., Harris, N. D. 1995. Maillard products inhibit apple polyphenoxidase. Food Chemistry, 53, 267-273.

Varela, P., Salvador, A. \& Fiszman, S. (2005). Changes in apple tissue with storage time: Rheological, textural and microstructural analyses. Journal of Food Engineering, $78,622-629$.

Viňa, S.Z. \& Chaves, A.S. (2006). Antioxidant responses in minimally processed celery during refrigerated storage. Food Chemistry, 94, 68-74.

Vorobjeva, N.V., Vorobjeva, L.I. \& Khodjaev, E.Y. (2004). The bactericidal effects of electrolyzed oxidizing water on bacterial strains involved in hospital infections. Artificial Organs, 28, 590-592.

Wang, H., Feng, H. \& Luo, Y. (2004). Microbial reduction and storage quality of fresh-cut cilantro washed with acidic electrolyzed water and aqueous ozone. Food Research International, 37, 949-956.

Willey, R.C. (1994). Introduction to minimally processed fruits vegetables. In: Wiley, R.C. (Ed.). Minimally Processed Refrigerated Fruits and Vegetables. Charman and Hall, New York, USA, pp, 1-4.

Watada, A.E. (1997). Quality maintenance of fresh-cut fruits and vegetables. Food Biotechnology, 6(4), 224-33

Watada, A. E., Ko, N. P. \& Minott, D. A. (1996). Factors affecting quality of freshcut horticultural products. Postharvest Biology and Technology, 9, 115-125. 
Figure 1 Flow diagram showing the procedure for the production of minimally processed fresh-cut lettuce treated with $120 \mathrm{mg} / \mathrm{L}$ chlorine (I), EW-120 (II), EW-60 (III) and EW-12 (IV) and stored for 7 days at $4{ }^{\circ} \mathrm{C}$.

Figure 2. "Endosteryl" device for washing and sterilisation of flexible endoscopes with the electrochemically neutral electrolysed oxidising water-type anolyte (I). Electrolysed water production (adapted from Hsu, 2003) (II).

Figure 3. Changes in headspace gas composition (oxygen and carbon dioxide) in headspace of packaged fresh-cut lettuce treated with $120 \mathrm{mg} / \mathrm{L}$ chlorine, EW-120, EW60 and EW-12 and stored at $4{ }^{\circ} \mathrm{C}$ for 7 days.

Figure 4. Cryo-scanning electron micrographs of fresh-cut lettuce washed with 120 mg/L chlorine (I), EW-120 (II), EW-60 (III) and EW-12 (IV) after 1 day of storage at 4 ${ }^{\circ} \mathrm{C}$.

Figure 5. Cryo-scanning electron micrographs of fresh-cut lettuce washed with 120 mg/L chlorine (I), EW-120 (II), EW-60 (III) and EW-12 (IV) after 7 day of storage at 4 ${ }^{\circ} \mathrm{C}$.

Figure 6. Texture test data. Effect of washing treatment on Maximum load/ Maximum displacement rate of fresh-cut lettuce treated with $120 \mathrm{mg} / \mathrm{L}$ chlorine (I), EW-120 (II), EW-60 (III) and EW-12 (IV) and stored at $4{ }^{\circ} \mathrm{C}$ for 7 days.

Figure 7. Luminosity (CIE L*a*b*) of fresh-cut lettuce treated with $120 \mathrm{mg} / \mathrm{L}$ chlorine (I), EW-120 (II), EW-60 (III) and EW-12 (IV) and stored at $4{ }^{\circ} \mathrm{C}$ for 7 days. 
Figure 8. Browning potential (Absorbance Units $\mathrm{g}^{-1}$ fresh tissue) of fresh-cut lettuce treated with $120 \mathrm{mg} / \mathrm{L}$ chlorine (I), EW-120 (II), EW-60 (III) and EW-12 (IV) and stored at $4{ }^{\circ} \mathrm{C}$ for 7 days.

Figure 9. Polyphenol oxidase (PPO) activity in fresh-cut lettuce treated with $120 \mathrm{mg} / \mathrm{L}$ chlorine (I), EW-120 (II), EW-60 (III) and EW-12 (IV) and stored at $4{ }^{\circ} \mathrm{C}$ for 7 days.

Figure 10. Microbial load (mesophilic bacteria) in fresh-cut lettuce treated with 120 mg/L chlorine (I), EW-120 (II), EW-60 (III) and EW-12 (IV) and stored at $4{ }^{\circ} \mathrm{C}$ for 7 days.

Table 1. pH, dry matter and water activity in fresh-cut lettuce treated with $120 \mathrm{mg} / \mathrm{L}$ chlorine (I), EW-120 (II), EW-60 (III) and EW-12 (IV) and stored at $4{ }^{\circ} \mathrm{C}$ for 7 days.

Table 2. Mineral content $\left(\mathrm{mg} \mathrm{L}^{-1}\right)$ after the washing treatment in fresh-cut lettuce treated with $120 \mathrm{mg} / \mathrm{L}$ chlorine (I), EW-120 (II), EW-60 (III) and EW-12 (IV) and stored at $4{ }^{\circ} \mathrm{C}$ for 7 days.

Table 3. Sensory evaluation (scores from 1 to 5 ) in fresh-cut lettuce treated with 120 mg/L chlorine (I), EW-120 (II), EW-60 (III) and EW-12 (IV) and stored at $4{ }^{\circ} \mathrm{C}$ for 7 days. 


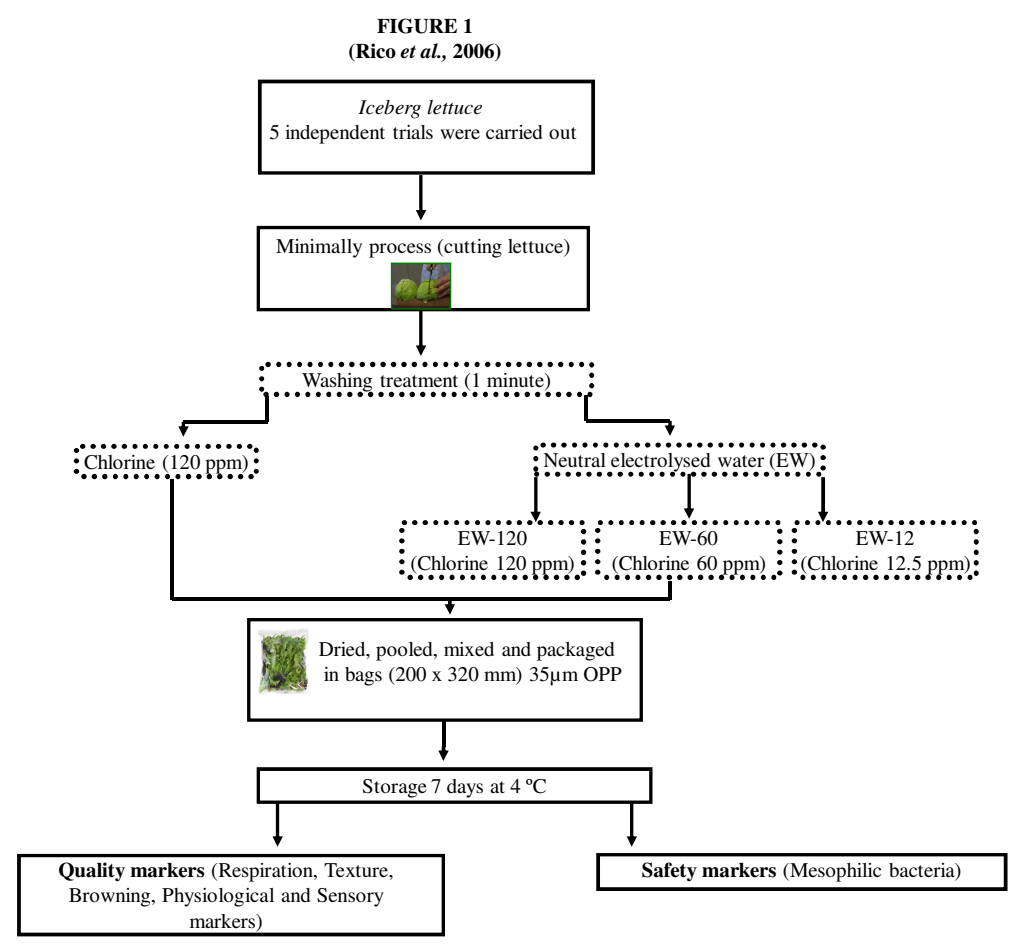

FIGURE 2

(Rico et al., 2006)
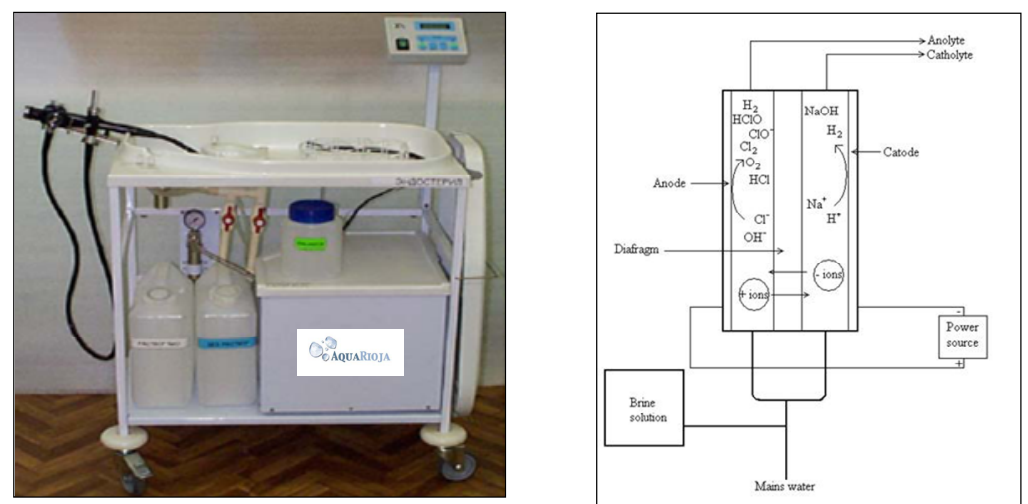
FIGURE 3

(Rico et al., 2006)

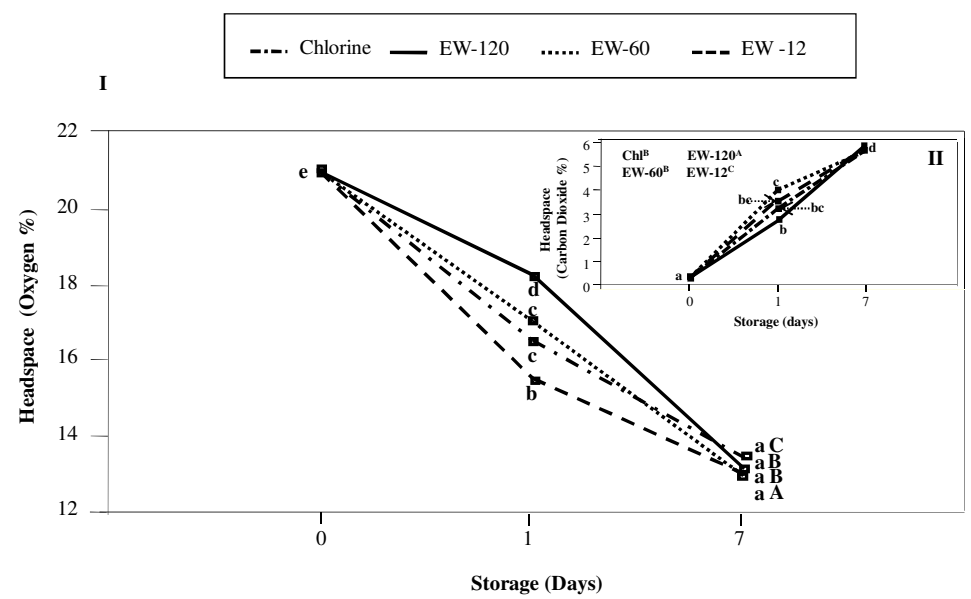

*Points designated on any curve by the same letter are not significantly different ( $p>0.05$ ). Lower case letters are used for comparisons during storage and upper case letters for treatment comparisons.

FIGURE 4

(Rico et al., 2006)

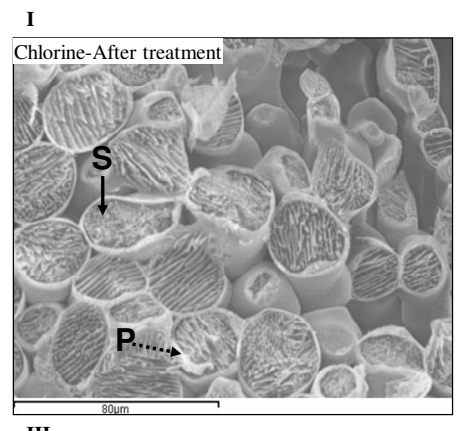

II
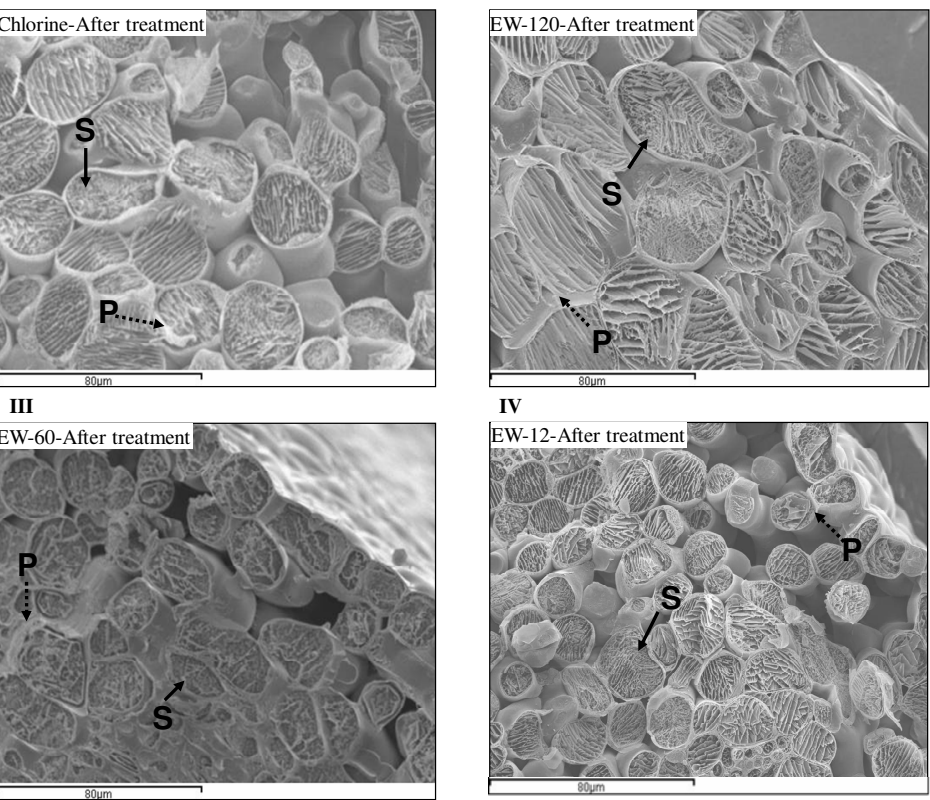


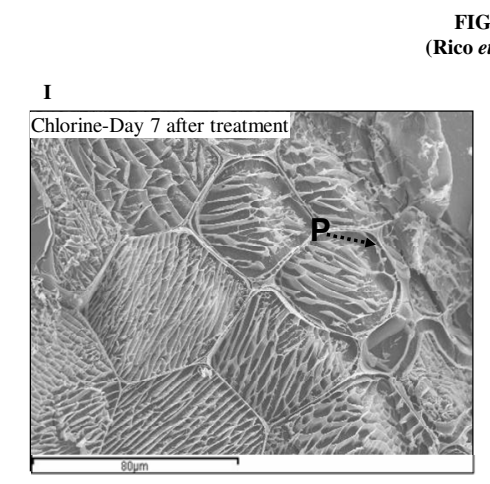

FIGURE 5

Rico et al., 2006)
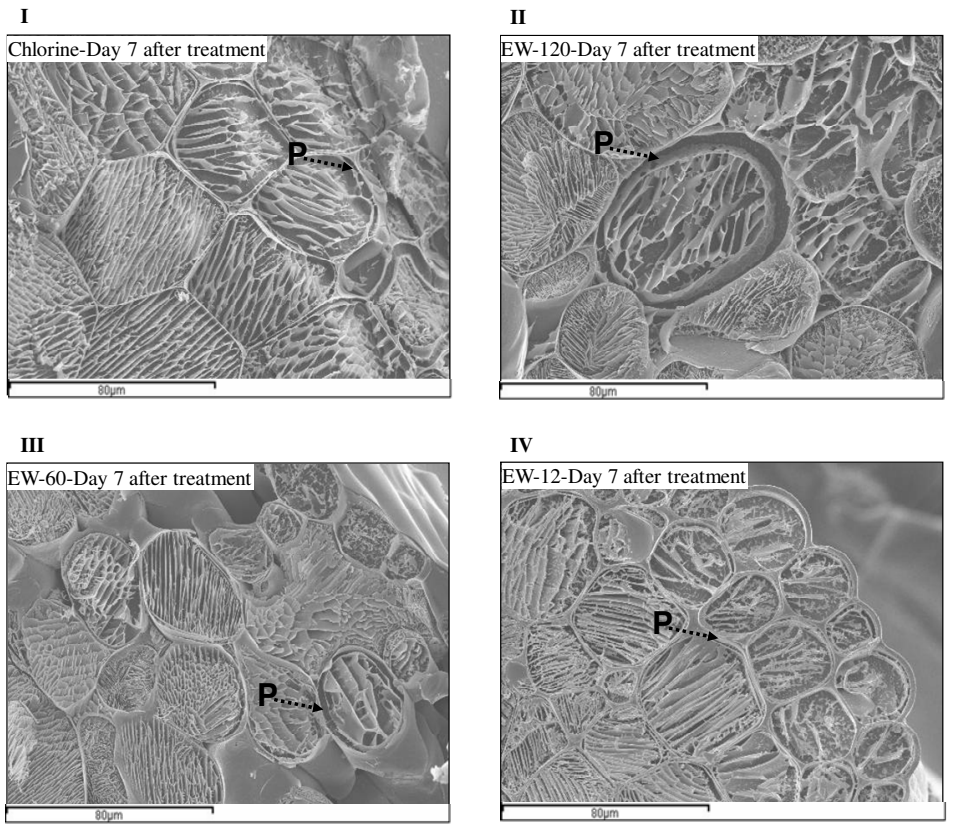

FIGURE 6

(Rico et al., 2006)

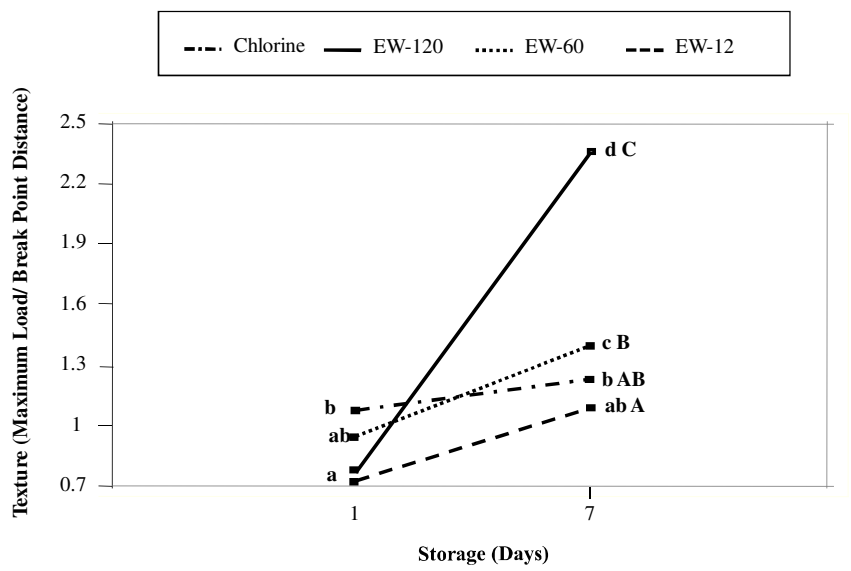

*Points designated on any curve by the same letter are not significantly different $(\mathrm{p}>0.05)$. Lower case letters are used for comparisons during storage and upper case letters for treatment. 
FIGURE 7

(Rico et al., 2006)

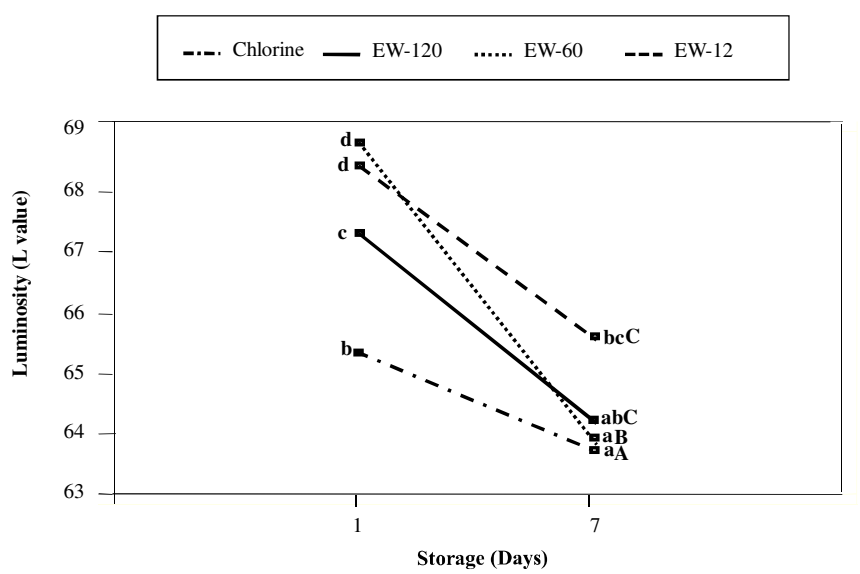

* Points designated on any curve by the same letter are not significantly different $(\mathrm{p}>0.05)$. Lower case letters are used for comparisons during storage and upper case letters for treatment.

FIGURE 8

(Rico et al., 2006)

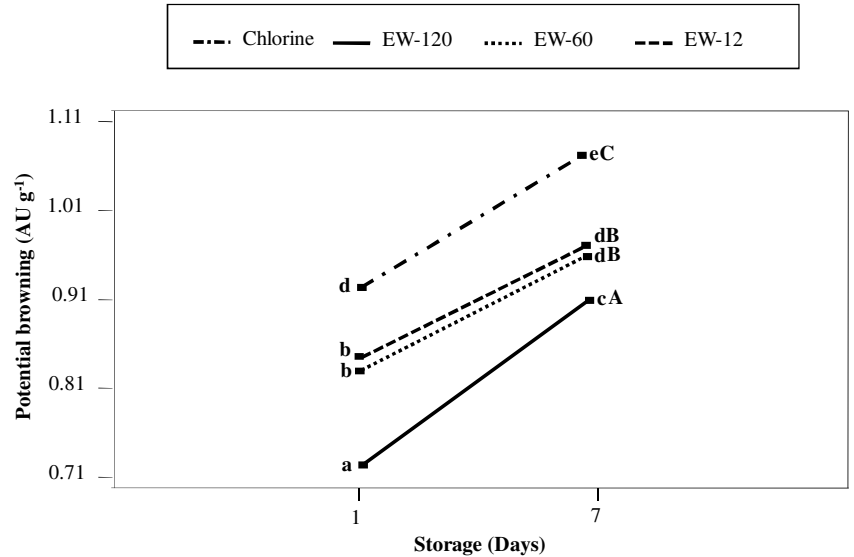

*Points designated on any curve by the same letter are not significantly different $(\mathrm{p}>0.05)$. Lower case letters are used for comparisons during storage and upper case letters for treatment comparisons. 
FIGURE 9

(Rico et al., 2006)

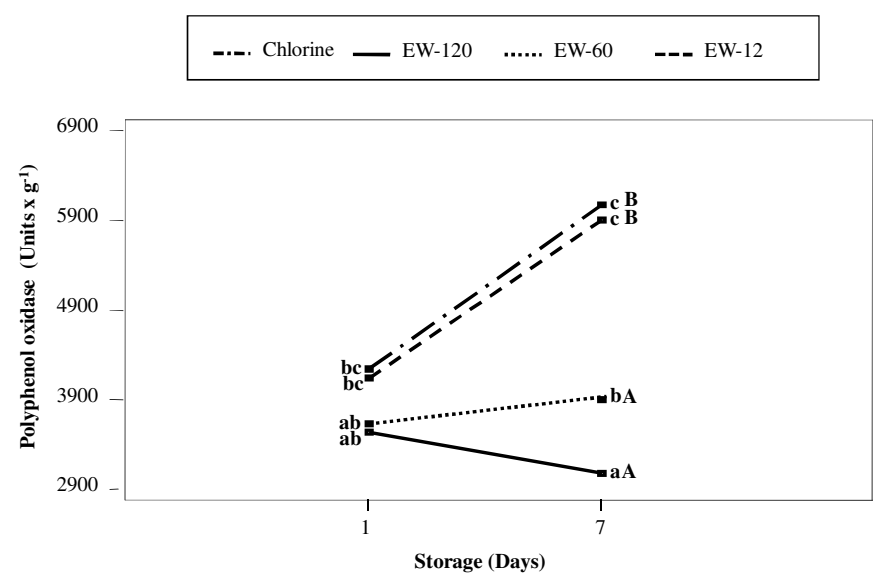

*Points designated on any curve by the same letter are not significantly different $(\mathrm{p}>0.05)$. Lower case letters are used for comparisons during storage and upper case letters for treatment comparisons.

FIGURE 10

(Rico et al., 2006)

-... Water -... Chlorine — EW-120 …... EW-60 --.. EW-12

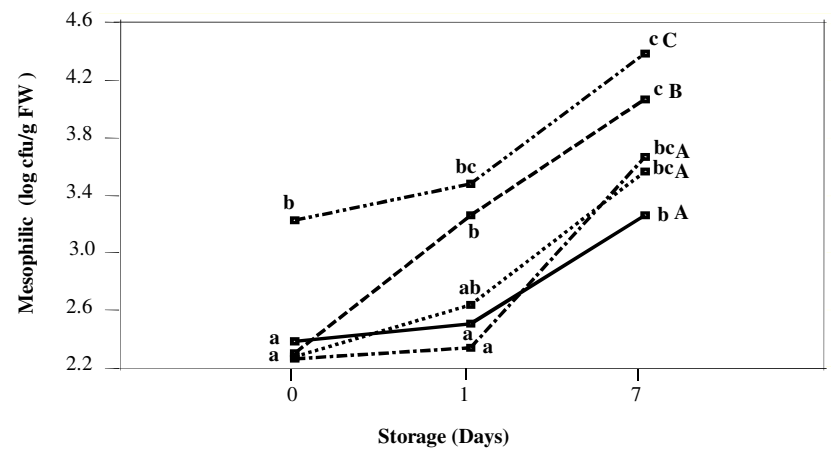

*Points designated on any curve by the same letter are not significantly different $(p>0.05)$. Lower case letters are used for comparisons during storage and upper case letters for treatment comparisons. 
TABLE 1

(Rico et al., 2006)

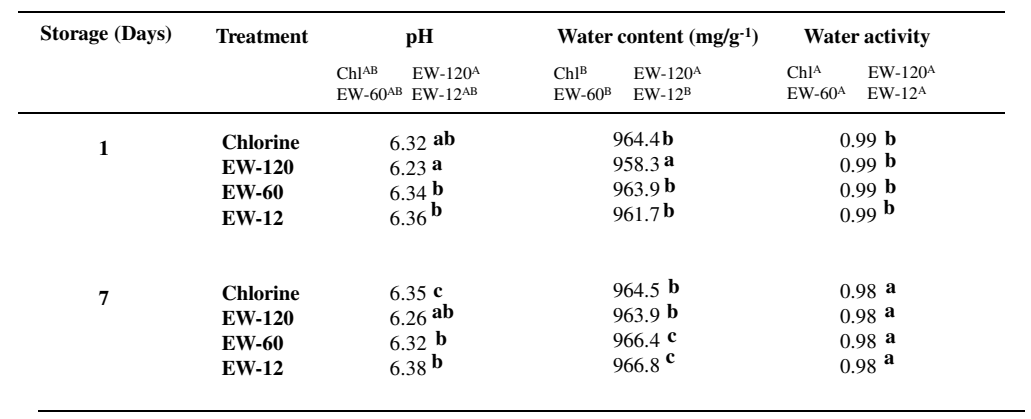

*Mean values. Values followed by different lower case letters in the same row indicate significant differences during storage Upper case letters indicate differences between treatments.

TABLE 2

(Rico et al., 2006)

Mineral Content at Day 1

\begin{tabular}{|c|c|c|c|c|}
\hline \multicolumn{5}{|c|}{ Mineral Content at Day 1} \\
\hline & Sodium $\left(\mathrm{mg} \mathrm{L}^{-1}\right)$ & Potasium $\left(\mathrm{mg} \mathrm{L}^{-1}\right)$ & Calcium $\left(\mathrm{mg} \mathrm{L}^{-1}\right)$ & Magnesium (mg L $\left.{ }^{-1}\right)$ \\
\hline \multicolumn{5}{|c|}{ Treatment } \\
\hline Chlorine & $0.0258^{b} \mathbf{b}$ & $0.1589 \mathbf{a}$ & $0.1220^{\mathbf{a}}$ & $0.0086^{c}$ \\
\hline EW-120 & $0.0237 \mathbf{a}$ & $0.1613^{\mathrm{a}}$ & $0.1613^{\mathbf{b}}$ & $0.0072^{\mathbf{a}}$ \\
\hline EW-60 & $0.0256^{\mathbf{b}}$ & $0.1870 \mathbf{b}$ & 0.1870 c & $0.0077^{\mathbf{b}}$ \\
\hline EW-12 & $0.0263^{\mathbf{c}}$ & $0.1820^{\mathbf{b}}$ & 0.1820 c & 0.0074 ab \\
\hline
\end{tabular}

*Mean values. Values followed by different lower case letters in the same row indicate significant differences during storage. 
TABLE 3

(Rico et al., 2006)

\begin{tabular}{|c|c|c|c|c|c|c|c|c|}
\hline \multirow[t]{2}{*}{ Storage (Days) } & \multirow[t]{2}{*}{ Treatment } & \multicolumn{2}{|c|}{ Fresh appearance } & \multicolumn{2}{|c|}{$\begin{array}{l}\text { Photosynthetic } \\
\text { Browning }\end{array}$} & \multicolumn{2}{|c|}{$\begin{array}{l}\text { Vascular } \\
\text { Browning }\end{array}$} & General Acceptabilit \\
\hline & & $\begin{array}{l}\mathrm{Ch}^{\mathrm{B}} \\
\mathrm{EW}-60^{\mathrm{A}}\end{array}$ & $\begin{array}{l}\text { EW-120AB } \\
\text { EW-120A }\end{array}$ & $\begin{array}{l}\mathrm{Chl} \mathrm{C}^{\mathrm{C}} \\
\mathrm{EW}-60^{\mathrm{A}}\end{array}$ & $\begin{array}{l}\text { EW-120 } \\
\text { EW- } 12^{\mathrm{BC}}\end{array}$ & $\begin{array}{l}\mathrm{Chl} \mathrm{Cl}^{\mathrm{C}} \\
\mathrm{EW}-60^{\mathrm{B}}\end{array}$ & $\begin{array}{l}\text { EW-120 } \\
\text { EW-12A }\end{array}$ & $\begin{array}{ll}\mathrm{Ch}^{\mathrm{B}} & \mathrm{EW}-120^{\mathrm{B}} \\
\mathrm{EW}-60^{\mathrm{AB}} & \mathrm{EW}-12^{\mathrm{A}}\end{array}$ \\
\hline \multirow{4}{*}{1} & Chlorine & \multicolumn{2}{|c|}{$4.36 \mathrm{c}$} & \multicolumn{2}{|c|}{$4.79 \mathrm{~d}$} & \multicolumn{2}{|c|}{$4.09 \mathrm{c}$} & $4.46 \mathrm{c}$ \\
\hline & EW-120 & \multicolumn{2}{|c|}{$4.26 \mathbf{b c}$} & \multicolumn{2}{|c|}{$4.77 \mathbf{d}$} & \multicolumn{2}{|c|}{$4.07 \mathrm{c}$} & $4.40 \mathrm{c}$ \\
\hline & EW-60 & \multicolumn{2}{|c|}{$4.04 \mathbf{b}$} & \multicolumn{2}{|c|}{$4.66 \mathrm{c}$} & \multicolumn{2}{|c|}{$4.09 \mathrm{c}$} & 4.21 bc \\
\hline & EW-12 & \multicolumn{2}{|c|}{$4.25 \mathrm{bc}$} & \multicolumn{2}{|c|}{$4.71 \mathrm{c}$} & \multicolumn{2}{|c|}{$3.77^{b}$} & $3.99 \mathrm{~b}$ \\
\hline \multirow{4}{*}{7} & Chlorine & \multicolumn{2}{|c|}{$4.30 \mathbf{b c}$} & \multicolumn{2}{|c|}{4.48 bc } & \multicolumn{2}{|c|}{$3.78 \mathbf{b}$} & $4.24 \mathbf{b c}$ \\
\hline & EW-120 & \multicolumn{2}{|c|}{$4.15 \mathbf{b}$} & \multicolumn{2}{|c|}{$4.37 \mathbf{b}$} & \multicolumn{2}{|c|}{$3.79^{\mathbf{b}}$} & $4.01 \mathbf{b}$ \\
\hline & EW-60 & \multicolumn{2}{|c|}{$3.66 \mathbf{a}$} & \multicolumn{2}{|c|}{$3.97 \mathbf{a}$} & \multicolumn{2}{|c|}{$3.10 \mathrm{ab}$} & 3.34 ab \\
\hline & EW-12 & \multicolumn{2}{|c|}{$3.71 \mathbf{a}$} & \multicolumn{2}{|c|}{$4.01 \mathbf{a}$} & \multicolumn{2}{|c|}{$2.82 \mathbf{a}$} & $3.25 \mathbf{a}$ \\
\hline
\end{tabular}

*Mean values. Values followed by different letters in the same row indicate significant differences during storage. Upper case letters indicate differences between treatments. 